\title{
ORIGINAL \\ BACTERIOLOGY OF SPONTANEOUS BACTERIAL PERITONITIS
}

\section{PROF-976}

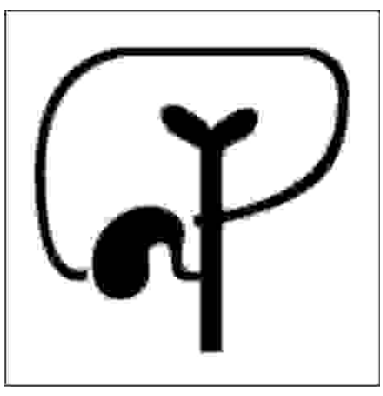

\author{
DR. DILSHAD MUHAMMAD, FCPS \\ Assistant Professor of Medicine \\ Independent Medical College Faisalabad \\ DR. MASOOD JAVED, FCPS \\ S/Registrar M U I \\ Allied Hospital Faisalabad
}

\begin{abstract}
Dr. Aamir Husain, MRCP (UK)
Assistant Professor of Medicine

Allied Hospital (PMC) Faisalabad
\end{abstract}

\author{
Dr. Abdul Qayyum \\ Registrar Omer Ward \\ Allied Hospital Faisalabad
}
DR. MUHAMMAD NAEEM IQBAL, M. Phil
Associate Professor of Pharmacology
Punjab Medical College Faisalabad

\begin{abstract}
Cirrhosis is a major cause of mortality worldwide and is the most common non neoplastic cause of death among hepatobiliary and digestive diseases. Ascites is often among the first signs of de-compensation in patients with chronic liver disease. Spontaneous Bacterial Peritonitis (SBP) (with out any source of infection) occurs in $30 \%$ of patients with ascites. Common causative organisms include escherichia coli, pneumococcus, Klebsiella and anaerobes. It has a $25 \%$ mortality and recurs in $70 \%$ of patients within a year. Objective: To determine the pathological agents causing SBP in patients with liver cirrhosis. Design: Descriptive study. Setting: Medical Ward Allied and K.M. Hospitals Faisalabad. Period: From 17 Nov 2004 to 15 May 2005. Patients \& Materials. Fifty patients of either sex having cirrhosis of liver and ascites were included according to the criteria i.e ascitic fluid leukocyte count of $>500$ cells/L or $>250$ PMN, while results of bacterial cultures of ascitic fluid were pending. Results: Out of 50 patients, 27 (54\%) were males and $23(46 \%)$ females. Mean age of whole the population was found to be $51 \pm 12.49)$ yrs. Classical spontaneous bacterial peritonitis was present in 27 patients and Culture Negative Neutrocytic Ascites (CNNA) in 23(46\%) patients. Out of 50 patients, $27(54 \%)$ samples of ascitic fluid showed positive culture reports. E Coli was isolated in $9(18 \%)$ cases. Klebsiella pneumoniae in 6(12\%), streptococcus pneumoniae 4(8\%), staphylococcus aureus 2(4\%), pseudomonas aeruginosa 2(4\%). Acinobacter 2(4\%) and proteus mirabilis 2(4\%). E.Coli is the commonest organism followed by klebsiella pneumoniae.
\end{abstract}

\section{INTRODUCTION}

Cirrhosis is a general term for end stage liver which can have many causes and which disrupts normal liver tissue. It results from necrosis of liver cells followed by fibrosis and nodule formation ${ }^{1}$. WHO has estimated that cirrhosis is responsible for $1.1 \%$ of all deaths. It 
comprises the $10^{\text {th }}$ most common cause of death in USA $^{2}$. Nothing is known about such figures in Pakistan but definitely the problem seems much bigger than what can be thought. Usual presentations are upper gastrointestinal bleed, ascites spontaneous bacterial peritonitis, hepatitic encephalopathy, hepatorenal syndrome and hepatocellular carcinoma ${ }^{3}$.

Patients with cirrhosis are very susceptible to infection of the ascitic fluid as part of their general susceptibility to infections. Acute bacterial infection without an obvious source of infection is termed as spontaneous bacterial peritonitis(SBP). The diagnosis is made when ascitic fluid neutrophil count is greater than $250 / \mathrm{mm} 3$ with positive ascitic fluid bacterial culture or ascitic fluid leutrocyte count greater than $500 / \mathrm{mm} 3$ and arterial ascitic fluid $\mathrm{pH}$ gradient is equal to or greater than $0.01 \mathrm{pH}$ less than 7.40 and lactate level greater than $25 \mathrm{mg} / \mathrm{dl}$. It may be culture negative neutrocytic ascites if PMN cell count is greater than $500 / \mathrm{mm} 3$, negative culture, absent intraabdominal infection, no antibiotic therapy in 30 days and no pancreatitis. If PMN cell count is less than $250 / \mathrm{mm} 3$ but bacterial are cultured from ascitic fluid, it is called bacterascites.

The ascitic fluid in cirrhotics typically has especially low concentration of albumin and other so called opsonic proteins, which normally may provide some protection against bacteria. The source of infection is not sually determined but most organisms are enteric origin and spread to the ascitic fluid by the haematogenous route after transmigrating through the bowel wall and traversing the lymphatics ${ }^{4}$. Common causative organisms include Escherichia coli, Pneumococcus, Klebsiella and anaerobes. Various studies have been carried out internationally to analyze the incidence, bacteriology of spontaneous bacterial peritonitis. Present study is also an attempt to determine the pathological agents causing SBP in patients with liver cirrhosis.

\section{MATERIAL AND METHODS}

The study was carried in patients admitted in Medical Unit I Allied Hospital and Khadija Mahmood Trust Hospital Faisalabad from 15 Nov 2004 to 15 May 2005.
Fifty patients of either sex having cirrhosis of liver and ascites were included according to the criteria mentioned below;

\section{INCLUSION CRITERIA}

Patients of cirrhosis of liver with ascites irrespective of age and gender. Cirrhosis of liver irrespective of its aetiology.

\section{EXCLUSION CRITERIA}

History of antibiotics or metronidazole therapy in the last preceding week.

Malignant ascites.

\section{PROCEDURE}

Applying full protocol of aseptic techniques, $20 \mathrm{ml}$ fluid was aspirated from each patient in a disposable syringe. $10 \mathrm{ml}$ of ascitic fluid was pt in commercially available broth bottle (biphasic culture system) and sent for bacterial culture. Rest of the $10 \mathrm{ml}$ ascitic fluid was sent for routine biochemical, cytological and gram staining. For cytological analysis, the timing of the paracentesis and the handling of the specimen was co-ordinated with the cytology laboratory. Biochemical analysis of ascitic fluid and serum were performed by Hitachi 704 autoanalyzeer, Boehreinger Mannhein, Mannhein, Germany. Ascitic cell counts and differential were done manually.

\section{STATISTICAL TEST}

Chi square test was applied $P$ values and standard deviation were calculated.

\section{RESULTS}

Out of 50 patients, 27 were male and 23 female i.e. $54 \%$ male and $46 \%$ female. Mean age of whole the population was found to be $(51 \pm 12.49)$ years.

Classical spontaneous bacterial peritonitis was present in $27(54 \%)$ patients and culture negative neutrocytic ascites CNNA in $23(46 \%)$ patients. Hepatitis $\mathrm{C}$ virus was detected in $34(68 \%)$, Hepatitis B Virus in 7(14\%), both viruses were absent in 5(10\%), both HCV \& HBV was detected in $3(6 \%)$ and $1(2 \%)$ was a case of alcoholic 
cirrhosis (table I). Clinically $32 \%$ patients presented with hepatic encephalopathy, $22 \%$ with abdominal distension and tenderness, $20 \%$ haematemesis and malaena, $10 \%$ with fever, $8 \%$ abdominal pain and $8 \%$ jaundice.

\begin{tabular}{|l|c|c|}
\hline \multicolumn{2}{|c|}{ Table-I. Distribution of patients according o cause } \\
\hline Cause & No. of pts & $\%$ age \\
\hline Hepatitis C Virus & 34 & $68 \%$ \\
\hline Hepatitis B Virus & 7 & $14 \%$ \\
\hline None & 5 & $10 \%$ \\
\hline Both & 3 & $6 \%$ \\
\hline Alcoholic cirrhosis & 1 & $2 \%$ \\
\hline
\end{tabular}

The mean ascitic fluid PMN cell count in typical SBP group was $1619.06 / \mathrm{mm}$. $27(54 \%)$ samples of ascitic fluid showed positive culture reports. E Coli was isolated $9(18 \%)$ cases, Klebsiella pneumoniae in $6(12 \%)$, Streptococcus pneumoniae 4(8\%), Staphylococcus aureus 2(4\%), Pseudomonas aeruginosa 2(4\%), Acinobacter 2(4\%) and proteus mirabilis 2(4\%) (Table II).

Table-II. Distribution of patients according to micro organisms

\begin{tabular}{|l|c|c|}
\hline Micro organisms & Frequency & $\%$ age \\
\hline No micro organisms & 23 & $46 \%$ \\
\hline Escherichia coli & 9 & $18 \%$ \\
\hline Klebsiella pneumoniae & 6 & $12 \%$ \\
\hline Streptococcus pneumoniae & 4 & $8 \%$ \\
\hline Staphylococcus aureus & 2 & $4 \%$ \\
\hline Pseudomonas aeruginosa & 2 & $4 \%$ \\
\hline Acinobacter & 2 & $4 \%$ \\
\hline Proteus mirabilis & 2 & $4 \%$ \\
\hline
\end{tabular}

\section{DISCUSSION}

Advance in medical science have resulted in prolonged survival of patients suffering from chronic diseases. In our country cirrhosis is becoming more common and becoming a burden for our hospitals. Infections is patients affected with liver cirrhosis are frequent, recurrent and associated t unfavorable outcome.

Present study is concerned with determination of different micro organisms causing spontaneous bacterial peritonitis. Mean age of patients was $51 \pm 12.49$ years. This means that underlying disease took considerable time to cause complications of cirrhosis of liver. Spontaneous bacterial peritonitis was detected in (54\%) of patients with liver cirrhosis having ascites. This figure is slightly lower as compared to that of $51 \%$, reported in a local study conducted by lqbal $S$ and his colleagues at Peshawar ${ }^{5}$. Another local study by Memon AQ and his colleagues at Nawabshah ${ }^{6}$ reported that $56.25 \%$ of the patient, were in classical SBP. This figure is comparable to this study at Faisalabad. But study from abroad Rubinstein $\mathrm{P}$ and his colleagues in Uruguay ${ }^{7}$ found out an incidence of $26.56 \%$ in cirrhotic patients. The probable reasons for such high incidence in our set up may be late referral ignorance, poverty \& malnutrition. Majority of our patients first consult local Hakims, who claim that only remedy of hepatitis is in herbal medication, which they prescribe.

Out of 50 patients with Spontaneous bacterial peritonitis, $27(54 \%)$ patients had positive ascitic fluid culture. This figure is comparable $42.15 \%$ with local study ${ }^{12}$. A study conducted in India by Jain AP and his colleagues ${ }^{8}$ stated that culture positive SBP was present in $(81.81 \%)$ and culture negative neutrocytic ascitis (CNNA) in (18.18\%). This figure is quite high as compared to this study. They also used the same method of ascitic fluid culture giving statement that Direct bed side inoculation of ascitic fluid into blood culture bottle was a better method for bacterial yield than the conventional method of ascitic fluid culture (81.8\% vs. 18.2\%). A study conducted abroad by Sae Ra Jung et al in Korea ${ }^{9}$, quoted that micro-organisms were isolated in $41 \%$ of total episodes. This figure is comparable to this study $54 \%$ vs $41 \%$.

Current study revealed etiology of cirrhosis in cases included to be $68 \%$ due to hepatitis $C$ virus and $14 \%$ of 
cases were due to hepatitis $B$ virus. It is vivid that Hepatitis $C$ is contributing a major share regarding the etiology of cirrhosis. This signifies the role of hepatitis $\mathrm{C}$ virus in causing cirrhosis in our part of the world and also highlights the importance of presentation of hepatitis $C$ virus infection. The specific reason to acquire Hepatitis $C$ virus in surgical procedures e.g. C. section, during diagnostic procedures regarding genital tract examination and routine ear and nose piercing as a part of cultural tradition in female population and in male population tooth extraction by local unqualified dentists, more use of intravenous injections such as neurobion administered to them by quacks who do not maintain standard sterilization, barbers may also be a contributing factor in HCV transmission from one person to another. A study from abroad by Rubinstein $P$ and his colleagues in Uruguay ${ }^{7}, 15$ patients were of alcoholic cirrhosis and 02 autoimmune disease. This is in correlation with traditional habits. Our patients are usually post hepatitic while alcohol is the most common cause of cirrhosis in western patients.

The mean ascitic fluid PMN cell count in typical SBP group was $1619.06 / \mathrm{mm}$. The mean PMN cell count was $1870.68 / \mathrm{mm}$ in study conducted by lqbal $S$ and his colleagues ${ }^{5}$. Similar higher percentage of PMN leukocyte count in patients with spontaneous bacterial peritonitis has been reported by all the studies so far publishe $\mathrm{e}^{10,11,12}$.

In this study E.Coli was isolated in 09(18\%) cases while it was $25(58.13 \%$ ) cases in the study conducted by lqbal $\mathrm{S}$ and his colleagues ${ }^{5}$ and this figure is quite high when compared with this study. But a study conducted in India by Jain AP and his colleagues stated E.coli (22.22\%) and this is comparable with this study ( $18 \%$ vs $22.22 \%$ ). Klebsiella pneumoniae was the second most common organism, isolated in $12 \%$, a figure comparable to that of $18.60 \%$ reported by lqbal $S$ and his colleagues. Sae RA Jung et al $^{9}$ reported Klebsiella pneumoniae $15 \%$ which is comparable to this study $12 \%$ vs $15 \%$. Study conducted by Osztrogonacz $\mathrm{H}$ et $\mathrm{al}^{13}$ gave conclusion that $\mathrm{E}$ coli, Klebsiella pneumoniae, alpha haemolyzing streptococcus were isolated from ascitic fluid positive cases. This also revealed that E. Coli was the most common pathogen followed by Klebsiella pneumoniae.

While enteric gram-negative bacilli such as E. Coli are most commonly encountered, gram-positive organisms, such as streptococci, enteroccocci or even pneumococci are sometimes found in SBP nd anaerobes are found less frequently. SBP is more common than previously thought and still, inspite of antibiotic therapy, the prognosis is poor and recurrence of SBP is common ${ }^{14}$.This condition should be suspected in any patient of ascites with evidence of clinical deterioration.

\section{CONCLUSION}

The following conclusions are drawn from the study;

1. Spontaneous bacterial peritonitis is a quite common complication of liver cirrhosis with ascites.

2. Clinical presentation of the patients can be variable, some patients present with fever which may or may not be accompanied with rigors, others may present with jaundice, abdominal pain, abdominal tenderness and hepatic encephalopathy.

3. If the patient looks ill, hospitalization is required. There is frequently a very short window of opportunity in which to intervene to ensure a good outcome. If this opportunity is missed, shock ensues, followed rapidly by multisystem organ failure.

4. Males and females both are affected without any discrimination of sex.

5. E.Coli is the commonest organism followed by klebsiella pnaemoniae.

6. Infections are common complications in hospitalized cirrhotics. Patients with spontaneous bacterial peritonitis has bad prognosis. 


\section{REFERENCES}

1. Burroughs AK, Westaby D. Liver, biliary tract and pancreatic disease. In Kumar PJ, Clark ML, editors. Clinical medicine. $5^{\text {th }}$ ed. Edinburgh: W B Saunders, 2002: 335-404.

2. Grateh DR, Bacchi CE, Corey L. Hepatitis C and liver transplantation. Am J Gatstroentrol. 200;12: 12-16.

3. Malik IA, Tariq W. Viral hepatitis in Pakistan (editorial). Pakistan J Pathol. 1996; 4: 1-3.

4. Guarner C, Soriano G. Spontaneous bacterial peritonitis. Semin Liver Dis1997;17:203-17.

5. Iqbal S, Iman N, Alam N, Rahman S. Incidence of Spontaneous bacterial peritonitis in liver cirrhosis, the causative organisms and antibiotic sensitivity. J Postgrad Med Inst Dec 2004; 18(4):614-9.

6. Memon QA, Memon Ghulshan, Khaskheli A. Spontaneous bacterial peritonitis in cirrhosis with ascites. An experience at PMCH Nawab shah. Med Channel Mar 1999;5(1): 31-4.

7. Rubinstein $P$, Morales $M$, Pandiani A, Bagattini JC. Spontaneous bacterial peritonitis in hepatitic cirrhosis with ascites. Incidence, bacteriology and mortality in Uruguay. Acta Gastroenterol Latinoam. 2001 Oct ; 31(4):307-12.
8. Jain AP, Chandra LS, Gupta S, Gupta OP, Jajoo UN and Kalantri SP. Spontaneous bacterial peritonitis in liver cirrhosis with ascites. J Assoc Physicians India, 1999 Jun;47(6):619-21.

9. Sae Ra Jung, Han Chu Lee, Young Hwan Park, Hee Gon Song, Young Hwa Chung, Yung Sang Lee et al. Clinical and Microbiological Characteristics of Spontaneous bacterial peritonitis (SBP) in a recent five year period. Korean J Hepatol 2002;8:61-70.

10. Runyon BA. Ascites and Spontaneous bacterial peritonitis. In Feldman M, Friedman LS, Sleisengeer MH, eds. Sleisenger and Fordtran's Gastrointestinal and liver disease. $7^{\text {th }}$ ed. Philadelphia Saunders, 2002:1517-42.

11. Jaffary W, Shah H Hamid S. Spontaneous bacterial peritonitis. Specialist 1992; 8(3): 33

12. Runyon BA, Canawati HN, Akriviadis EA. Optimization of fluid culture technique. Gastroenterology, 1998;95:13515.

13. Hoefs JC. Diagnostic paracentesis a potent clinical tool. Gastroenterology 1990;98:230.

14. Parsi MA, Atreja A, Zein NN. Spontaneous bacterial peritonitis: recent data on incidence and treatment. Cleve Clin J Med 2004Jul; 71(7): 569-76.

\section{SUCCESS IS NOT ACHIEVED IN A DAY.}

Shuja Tahir 